\title{
African Oral Literature as a Tool for National Development: An Examination of Tiv Oral Poetry
}

\author{
Terlumun Kerekaa \\ Department of English, Benue State University, Makurdi
}

\begin{abstract}
This paper surveys the significant contributions that African oral literature has made as a tool for national development. The presentation uses Tiv oral poetry as the major specimen for examination. Renditions of different bards as they border on the subject in question in Tiv land were examined. The study particularly projected the relevance of Tiv oral poetry in the context of the modern society which transcends the traditional thematic preoccupations. It located the significance of oral poetry as a veritable tool for championing the struggle for socio-economic and political change. The research also re-examined the primordial image of African oral literature as projected by Western scholars. It recommended that such erroneous knowledge must be excised for African oral literature to take its rightful place among literatures of the world. Finally, the research hopes to provoke other scholars to study the other aspects of Tiv orature as tools for national development.
\end{abstract}

DOI: $10.7176 /$ JLLL/57-03

Publication date:June $30^{\text {th }} 2019$

\section{Introduction}

One of the critical consequences of the transition from oral literature to written formthat is frozen and cast hard in print is the paucity of recognition of the role of oral literature in national development. For instance, there is a disturbing evidence of a dearth of recognition of Tiv oral poetry as a tool for national development. The fact is, the role of this expressive and emotive oral art form among the Tiv of Central Nigeria in national development have received extremely sparse recognition in the scholarly circle. This is rooted in the praxis of sheer sentiment that oral literature belongs to the non-literate society and therefore, lacks capacity for development. With the emergence of the written form of literature, the expressive oral form of literature has suffered the stigma of inferiority and certainly what should not be heard of in a literate society.

This well-trodden platitude guided by colonial sentiments has effectively been put to rest by the evidences established to the contrary in the contributions of numerous oral poets to the development of humanity in general. In Tivland for instance, almost every critic knows, for example the contributions of oral poets like Ityavger Fate, Tarker Golozo, Obadiah Orkor, Tondu Kumbur, and Oliver Aye - the list is inexhaustible - have all contributed immensely to national development in their numerous artistic renditions.

At present, literary scholars have been increasingly inclined to be persuaded about the formal conventional features of oral poetry as a genre of literature. They are beginning to recognized and investigate oral renditions as poetry, looking for its stylistic features and not anthropological artefacts as the works of imperial anthropologists and sociologists earlier portrayed. In collaboration, Janheinz Jahn earlier bemoans this fact that:

(Western) scholars continued to collect African poetry but did not investigate it as poetry looking for its stylistic rules...it has remained a treasure trough of all manners and customs, a store house of vocabulary, a reservoir of archetypes, an inexhaustible source for histories, a training ground for the phonetician, a quarry for the anthropologist, a paradise for myth collectors. But as literature, as poetry, it has remained unexplored territory. (56)

Jahn's assertion rightly draws attention to the sad experience that indigenous African literature went through in the hands of imperial scholars who midwife the birth of literate society.

However, fortunately or unfortunately, there is an awakening of a synthesizing view of oral literature as having the capacity to stand on the same platform with western written literature in the development of the human society. Indigenous scholars are revisiting the same field of exploration and voices of doubt are been heard. The imperial forces in attempt to murder African indigenous literature tagged it crude and barbaric prefatory terms; which at the surface, this appears to be a definitive branding; a categorizing of a kind of literature, but in reality it is an assault on the indigenous literature of Africa. It was a psychology to permanently stamp out African oral literature from its privilege position as an African heritage. As such, they denied it the privileged generic uniqueness and a sense of formal conventions. There was no systematic scholarly attention given to it as literature. Western critics in a bid to enshrine a superior culture, paraded fashioned prejudice that tried to shaped critical thought for hundreds of years with blanket theories. However, that imperial iron curtain is has finally given way. In its place, a richer and more soundly based world view has grown which recognizes the immensity of oral literature as a rich and original literature with the capacity to stand shoulder to shoulder with Western literature. This is a great restoration that the Canadian novelist and critic Margaret Laurence saw many years ago. She succinctly submitted that: 
No writer of any quality has viewed the old Africa in an idealized way, but they have tried to regain what is rightly theirs - a past composed of real and vulnerable people, their ancestors, not the figments of missionary and colonialist imaginations. (9)

Laurence assertion draws attention in a manner of seers to the restoration of the status of oral literature. Thus in a way heralded the significantly the future of African oral literature generally. For instance, in a recent scholarly output, Yina recognizes this fact more strongly about Tiv oral poetry in particular:

Like the written poetry of western culture, Tiv oral poetry constitutes a self-conscious, highly allusive and creative verbal art form. As a communication system, the poetry is dressed in measured rhythms of appeal and contains verbal aspects of customs and observances of the people. The traditional poet possesses high powers of imagination and figurative expression. His knowledge of cultural metaphors symbolically places him in a position to determine and influence the meanings which rule and direct the lives of people in the society. (4)

Yina's assertion acquires the exactitude of literal truth, because like written literature, oral literature in many instances aspire to contribute to the development of humanity. It has in its outing as an expressive imagination and the persuasive prowess to impress on the human mind. And when a people are positively influenced, it is a huge contribution towards national development.

This is what Roman Jakobson defines as "the poetic function of language" where there is a fusion of art and language and a deeper form of communication is realized. He further elucidated that "Art is subjective, it "affect" the subject that is to say, it touches the human organism or psyche by means of an impression or action" (69). Oral poetry in its nature and rendition profoundly affects the human mind. In fact, among the Tiv people, the urge to influence the audience through performance is an integral impulse of oral poetry woven with strings of aesthetics. The rhythmic rendition so stimulates sustained emotional responses in the audience. This disposition of the oral art form draws attention to its importance as a tool for national development. In fact, it is quite difficult for the Nigerian society to dispense with the need of oral literature.

Another preliminary chore in this ensuing discourse is "national development". In the Tiv world view "national development" is described by two words: Tar sôrun and mzehemen. Literally, these two words mean "treating the world or nation" and "progress" respectively. The implication is that the world has gone bad and needs treatment as there will be no progress in the world or nation that is in the state of depravity. Therefore, for national development to take place, the nation must be first treated of her depravity.

It is a common knowledge that Nigerian writers have responded through prose, poetry and drama to issues regarding national development in the country since the emergence of the modern Nigeria. Ethnic and religious crises, insurgence, kidnappings and herdsmen invasion have continued to hamper the development of this most populous Africa country. A massive disillusionment has settled heavily on the country and its democracy is resident in profound depravity. The witness to the miseries of underdevelopment and ineptitude of leaders in the nation has made a vast spectrum of the populace to clamour for tar sôrun nation treatment in Nigeria. Olu Obafemi earlier maintains, correctly, that:

...at no point in our history, not even in the season of fratricidal carnage of the Nigerian Civil War of 1976 to 1970, has our nationhood been more threatened with dismemberment or ...disintegration. We live literally in a deluge of blood. Our streets are crimson red with the blood of our neighbours, our kinsmen and women. It is indeed a cannibal rage; the return of the season annubiale and anomie. It is an intriguing paradox that jus when we are supposed to be relishing the gains of a return to democracy, with all the freedoms that it must bear freedom of speech, of association, of worship, from want, squalor, poverty and hunger - we engage in a macabre dance of death and horror, all at the alter [sic] of religion and tribe. (1)

Obafemi has graphically presented the nation's depravity appropriately. He goes on to stress that "Everywhere, in our country, there is a cry of anguish and mutual distrust" (2). Femi Osofisan also offers a reflection of the state of the nation in his play Midnight Hotel and later in Nightwatchmen. Moses Tsenôngu among many other poets also has assorted volumes of poetic anthologies that reflect issues of national development. All these literary productions are a clamour for national development.

The literary response to issues of national development is not limited to written literature alone. Even in oral literature, issues of national development have been a handy raw material for literary exercise. Apart from the traditional themes, many oral poets sing about issues that thematically have bearing on national development. The songs are usually woven through observable reality about topical issues. Oral poetry for instance, does not only carry figurative expressions that entertain its audience, but also inform and influence the people's thought patterns and feelings. These spans through politics, state of the economy, education and leadership in the country. It is against this background that this paper examines the role of Tiv oral poetry and its contribution in national development. 


\section{Tiv Oral Poetry and National Development}

One indubitable fact established by scholars about the Tiv of Central Nigeria is the existence of immeasurable wealth of indigenous poetry among them. A peculiar feature of Tiv oral poetry is that it serves an aesthetic mode of traditional discourse within the ambience of the community's speech repertoire. Development considered as mzehemen in Tiv is a social phenomenon that is prevalent in Tiv oral poetry. There are numerous oral productions that bear witness to this fact in Tivland. For instance, oral poets like Bam Ginde, Amee Jorpo, Ajo Agoo, Tarker Golozo, Obadiah Orkor and Oliver Ayeh among many others rendered assorted poems bordering on national development.

Nigeria as a country experienced the fratricidal carnage of civil war from 1967 to 1970 that threatened the corporate existence of the country in which many Tiv veterans fought to keep the nation together. Here too Tiv oral poetry proved its significance even in the war front as many Tiv bards were performed for some of their patrons who were in the military. What this means is that Tiv oral poetry was at a point in time performed outside of Tivland. It is only natural to submit that, the oral performance was certainly a source of inspiration to the Tiv veterans who were physically engaging the enemy in battle. Moses Terhemba Tsenôngu in his undoubtedly the most insightful research on the periods of Tiv oral poetry shades more light on the contributions of Tiv oral poetry at that time:

During the Nigerian Civil War, these poets contributed much in maintaining high spirits in Tivland. In fact, some of them (Agugu Igbyakumbul and Kuje Iyum for instance) were actually taken to the warfront by some of their military patrons to entertain Tiv soldiers. (87)

Tsenôngu also draws attention to the contribution of oral literature to national development. The Nigerian history will not be complete if the role that oral literature played to keep the nation as one is denied its rightful space. The Tiv oral poets may not have fought physically at the warfront, they may not have kept the guns roaring, but they sing to keep the spirits of the soldiers high and prevent Nigeria from dismemberment.

Besides, the Tiv of central Nigeria are reputable and skilful warriors; many of them participated in the two World Wars and also fought to keep Nigeria one. It must be submitted here that engaging poetic performance at the warfront is a common phenomenon among them. In the Tiv world, song rendition serves different purposes as it displays a diffusion of emotional intensity. It can be a lulling art to put a child to sleep, a praise to a personality, an aspect of worship or healing, a companion for a thoughtful moment, a dirge or an expression that elicit violent and spontaneous responses for a war. Tesemchi Makar in A History of Political Change gave an insightful description about this aspect that:

They the fighting men followed at night carrying with them the "Indyer" drum to the new territory. They often chose their outpost close to the settlement of the "atoatiev" found in the area. There, they set up the Indyer drum and played, dancing, shouting and singing. After they had finished dancing they concealed the Indyer drum and then withdrew to wait... (quoted in Yina Semiotics...(102)

The emotive nature of poetry makes it a veritable instrument for heightening the morale of warriors and again throwing the enemy warriors into terror.

Entertainment is not the only preoccupation of Tiv oral poetry. The expressive nature of oral poetry makes it a veritable for education, information and propaganda about government policies. Oral poets are actually the bearers of the humanistic burden and serving a socio-cultural function of entertainment, education, information and preservation of societal values and social conduct. Yina shares the same insight that:

Apart from the aesthetic function of Tiv traditional oral poetry, certain songs by renowned artists serve as direct government propaganda to educate the people on her policies and actions and to encourage people to adopt better living standards, especially in matters of health and agriculture. (114)

Yina rightly draws attention to the fact that, the emotive nature of oral poetry makes it a suitable tool for government propaganda on policies. The writer intends to observe here that oral poetry serves a better tool for this particular task because it speaks the language of the people and they could decipher meaning faster than situations where the English language is employed. The oral poet usually uses traditional repertory of images and cultural metaphors to communicate to his audience. For instance, contributing to the importance of agriculture and food security to national development, Golozo stresses the value of fertilizer application in one of his poems titled "Fertilizer" that:

Mza yam icigh er me naha naha

Tso m yila Awuhe Pever

Tesem er me wa ver me kera was ha ibume ga yô,

$\mathrm{M}$ wa icigh yô $m$ dugh doya

Kwagh hingir kôngulôo,

Agbo ngu alu kôngulôô,

Logo wam kpa kôngulôô 
Kua di mba mondo u kaka ne

Mondo ngu a lu kôngulôô

\section{Translation:}

I went and bought fertilizer as if to prepare corn meal

Then I called Awuhe Pever

To instruct me on how to apply correctly

So as I will not apply foolishly.

I applied and harvested yam

It was smoothly

Water yam was smoothly,

My cassava was smooth

Even mere cocoyams

Cocoyams were exceptionally smooth

In the above poem, the oral poet addresses the public especially farmers on the need and methods of fertilizer application. He is instructing farmers to avoid misapplication of fertilizer on farm lands. That fertilizer application is a new and modernized form of farming in Tiv land at the time the particular poem was rendered is a general knowledge. Yina shares the same sentiment earlier on that:

Recall that fertilizer application is a latest technology in Tiv farming experience. Many farmers in Tiv land had scalded their crops with fertilizer. Thus many were sceptical [sic] for fear of a similar occurrence. It was therefore, pertinent for government to ensure an enlightenment campaign to get the people out of their ignorance. (117)

The oral poet Golozo, gladly undertook this task of educating the Tiv populace on this matter in teaching farmers on fertilizer application. This confirms the significant role of oral poetry as a tool for mobilization and education in the society with regards to government policies.

Apart from the surface propaganda, Golozo employs visual imagery which makes the message more impactful. The aesthetic appeal of visual imagery in the poem lies in the way it provokes a sense of sight, graphics, visual scenes or pictures in the minds of his audience. This lies especially in the hyperbolic language employed in expressing the effects of fertilizer application on crops. The oral poet arouses the curiosity of his audience by graphically painting the picture of the huge harvest where every crop was admirably smooth including cocyam that is naturally rough. This rendition will certainly recruit more farmers in fertilizer application. Therefore, in the area of agriculture, oral poetry has proven useful as a tool for national development.

In another outing, the renowned oral poet, Golozo again lent his voice in warning the Tiv people about the destructive effects of drinking ogogolo - local dry gin. Consumption ogogolo was at a point in time in Tiv land so prevalent that the paramount of ruler of the Tiv nation, His Royal Majesty, Tor Tiv III, Akperan Orshikur Ubaka had to engage in the war against ogogolo in Tiv land. The oral poet warns:

Tor Tiv Akperan Orshi ngu yôôn er

I de man gogolo, i kaha a kaha kwagh

Gogolo doo ga

Gogolo vihin or a or u nan

Shi gogolo panden tahav.

Or gogolo yan tsa hen amo

Kper nan m gba yaren shin ityev

M kaa mer a mough sha se yar

Venda kpa m sendegh yo gba yaren

Sha lanshima tsô,

Za ngurum u kahan yô

Sen tume dzwa inya ooo.

\section{Translation}

Tor Tiv Akperan Orshi is announcing that

People should stop drinking ogogolo but should farm instead,

That ogogolo is dangerous

Ogogolo destroys relationship

And also reduces strength.

A drunk once slept in my house,

I was going to farm the following day

And I asked him to accompany me

He refused, but I insisted. 
Reluctantly he accompanied me,

As he bent to farm

He fell down hitting his mouth to the ground.

Here, the oral poet clearly points out the destructive effect of ogogolo on his customer by rendering them unproductive. He dramatizes such destructive effect on relationships and agricultural activities for his audience to see. At a time that the nation is fighting food security through "Operation Feed the Nation Campaign", the import of this poem is impactful. The rendition is serving as information and a warning. The aesthetics of the poem is in the fusion of drama and poetry to reach out to the audience. Silently, the oral poet like a seer is sounding an alarm of famine that would come upon Tiv land if the people would not stop the consumption of ogogolo. This has also demonstrated the importance of oral poetry in national development by contributing to the socio-economic development.

Politics generally is a national subject and it has all along from inception been a ready creative material for oral poet for his literary exercise. Tejan Sellah shares the same sentiments that poets:

...assume the task of art for social advocacy in the hope of quickening the possibility of attainment of a better world... they have employed their art to engineer positive social change. They are poets who have learned to employ the magical potency of language in order to radically alter the landscape of complacent minds and inspire them to fashion a more humane future. (16)

Sellah is right in the above observation, because the oral poet is conscious of the socio-political realities in his environment and this fact relevantly informs his poetic adventure. It is on this premise, that the contribution of Tiv oral poetry towards national development will again be examined.

Many oral poets have profound knowledge concerning politics and therefore, stand a good chance of educating and mobilizing his audience to actively participate in political activities. In fact, Golozo as an oral poet was in the forefront mobilising the Nigerian populace in the political dispensation. As the elections were approaching, the oral poet counsels that:

Tyô yam Ishagen ngi van

Yô de veren kwagh u inyar ken hemen ga

I sange ior mba ve lu a inja yô

Or a lu a naira ga kpa nana doo yum yô,

Tyô yam ne sange nan.

\section{Translation}

My people, elections are coming

Do not consider money first

Elect people of good characters

Even if one does not have naira but is good

My people elect such a person.

One of the interesting qualities about this particulate oral poet is his boldness in handling weighty issues in his poems. This was the nature of oral poets at this age - they were concerned and made categorical statements on issues on nationhood in their poems. Tsenôngu earlier shades more light in this direction that:

...thematically, because of the Nigerian independence, poets of the Golozo age, in addition to the traditional themes, sang about the issues of nationhood. They were either questioning of fuel scarcity in the country, or proclaiming the goodness of fertilizer, or preaching adult education, or educating the people on some forthcoming census, or celebrating the creation of one State or Local Government Area or another, or singing praises of one politician and political party or another. (87)

The politics of money commonly called "money bags" has distorted the Nigerian political arena right from inception. The oral poet therefore makes therapeutic statement and at the same time mobilising his people through the above lines. He counselled that the issue of money should be de-emphasized in the country and people of integrity be elected to serve.

Obadiah Orkor is another renowned poet whose poetic adventure also touched politics. The hostility encounters between the Tiv people and Jukun in Taraba state has been a creative material for many oral poets among which Obadiah is prominent. The oral poet draws significant attention to boundary issues. In one of the poems he sang praises of the late governor of Benue State, Aper Aku for swinging into action the moment he was elected. The oral poet avers that: Er yange Gomna Aku unde ikônough

Tsuwa sanker gbidye nyinya yem

Wukari za tile gba saar tyô yam

$M$ hide $m$ se kera 
Er ankpan dzurum u duen ken kpan sha-ooo

\section{Translation}

On installation Governor Aku

Rode gallantly on horse-back with a drawn sword

To Wukari to reassert my birth right,

It thrilled me

Like a slave about to regain his freedom.

The gallantry imagery employed in the above lines is emotive and has dramatized the message and made it impactful. There is a strong suggestiveness that the governor is ready to settle the boundary issue and stop all forms of harassment. The rendition is capable of emotional stirrups.

Oral poetry is a purposeful venture and its relevance in national development cannot be ignored in the modern society. The oral poet who is the custodian of the art assists the society in areas of education, information and to champion the struggle for social justice. Ayem Shoja also stressed this fact about Tiv oral poetry been instrumental to national development that:

In the area of national development, one observes that right from the 1960s Tiv oral poets have been instrumental in the propagation of government programmes. Such oral poets like Tarker Golozo, Aju Ajôô, and Agugu Igbakumbur contributed in the enlightenment campaign on the national census exercise. Tarker Golozo had championed social mobilization on the use of fertilizer as well as the voters Registration among other government progrmmes[sic]. (6)

The above assertion again brings to light the fact that oral literature generally is committed to the development of mankind. The nature, aim and deepest aspirations of oral literature in all props fashioned at different times are for the development of humanity; whether it was for entertainment, education, propaganda, information, healing or preservation of ethno-cultural histories and norms. It is an art that is principally put to the service of social, economic, cultural and political reconstruction of the society.

Lending a voice in condemning the military invasion and wanton destruction of lives and property in Tiv land in 2001, another renowned oral poet, Oliver Ayeh responded alongside intellectuals philosophically as thus: Ka we a va num u kôrun Unyôr ior mba nôngun her atô, Ngula a nule a tagher sha awe Ngula a nule a tagher sha awe Num u bee ye.

\section{Translation}

When you come to separate fighters

You stand in their middle

When one makes a move, he is blocked

When the other makes a move, he is also blocked

Then the fight is brought to an end.

The appeal in the above poem is where the poet uses the imagery of peace keeping to boldly draw the world's attention to the unjust operation where the Nigerian Army took side with the Jukun. He questions the unethical motive behind the genocide as the peace keeping operation resulted to the killing of thousands of Tiv people and burning down several villages in Tiv land. The oral poet knowledgably stressed that:

Shoja va num u kôrun yô

Shoja nande Abako, shi ve nande agar

A Tiv nzughul-nzughul.

\section{Translation}

The soldiers came on peace-keeping mission

They burnt down Abako, and also

Burnt down many other Tiv villages anyhow.

The profundity of the message can be located where the oral poet graphically painted the razing down of villages - ve nande agar a Tiv nzughul-nzughul. The line pathetically carries with it an undertone of psychological trauma of the military invasion and brutality. It becomes necessary to submit that oral poetry as an indigenous art form very often serves as the voice of the society. The society can speak, laugh, sing, cry or whine through it. Apegba Ker agrees that "Thus, people have seen poets over the ages as being the society's voice of conscience, saying what many people would want said but cannot do so themselves (24).”

This is clearly demonstrated here in the above poem where Oliver Ayeh, the bard joined several reputable voices across the world to call on the local and international community to investigate the incident as it 
amounted to genocide. Considering the responsibility of the oral artist in national development, the Ugandan poet, Okot p'Bitek avers that:

He [the oral artist] has talents which other members of the society and social group may not posses, of distilling the thoughts, joy, fear, anger, and sorrow, not only of the individual but also of the group and preserving these in melodic poems. (9)

p'Bitek draws attention to what many have failed to see- the task of the oral artist in national development. Every incident is a creative material for the oral artist to advocate for or educate his people. The incidence provided creative material for the oral poet and he boldly recreated attracted the attention of both the local and international community. In fact, Dan Isaacs of the BBC was reported in clear terms that:

What I saw appalling and I hope never to see it again, during my life time. The soldiers came in trucks and stopped at the market. They jumped off the back of the vehicles, cocked their guns and started shooting. The bodies were left for reporters to see... I have asked questions. Did the soldiers say anything first? Was there any fighting going on in the town? Did they appear to be hunting down militia leaders? And the answers I got to each question was no. They just rolled their guns and started shooting. And across the town, every house, every shop, every office... every single building has been destroyed by fire. (BBC Nov. 3, 2001)

The BBC import corroborated what the oral poet has said earlier in his rendition. The killing of innocent and unarmed citizens of the country by members of the arm forces whose duty is to provide security was quite unfortunate. This places the oral poet in a position to speak for his people as he does not only entertains, but also informs and influences the society's thought and feelings. This demonstrates that the oral poet occupies a prominent position in creating social awareness and political consciousness.

\section{Conclusion}

All along the above discourse, Nigerian history has demonstrated and proved times and again that, oral literature generally but particularly Tiv oral poetry has contributed immensely towards national development. It is therefore, downright impertinent, for anyone, but especially an African scholar to embrace the contemplative idea that oral literature has no contribution towards national development. It will be a repetition of Eurocentric idea, an error that was originally invented to distort the growth of African indigenous literature. For oral literature plays a major role in propaganda concerning government policies, informing and speaking for the society in expansive, diverse and increasing doses.

The world today applauds the contributions of written literature towards national development, but is strangely unaware of the roots of written literature tightly buried in oral literature. So going forward, the imperial veil casted upon oral literature which has given it a stereotypical image must be excised. African oral literature must be given its pride of place among literatures of the world in scholarship and in the society. The natural, irresistible allure of oral literature must be sincerely appreciated outside the primordial imperial prism of critical thought. Finally, it is hope that this piece of research will provoke other scholars to return to the same field with a fresh impetus to discover interesting gaps deliberately or ignorantly left by foreign missionaries, anthropologists, sociologists, historians etc who scholarship were anything but literary.

\section{Works Cited}

Jakobson, Roman. "Language in Relation to Other Communication System" World and Language. The Hague: Mouton, 1969.

Jahn, Janheinz. Muntu: Neo-African Literature. London:Faber and Faber, 1968.

Ker, Apegba. Tiv Poetry and Politics: A Study of Tarker Golozo. Auja: Akia, 2002.

Laurence, Margaret. Long Drums and Cannons. London: Macmillan, 1968

Makar, Tesemchi. A History of Political Change among the Tiv in the $19^{\text {th }}$ and $20^{\text {th }}$ Centuries. Zaria: 1975.

Obafemi, Olu. "The Humanities and the Challenges of National Integration" in Journal of Faculty of Arts Seminar Series

p'Bitek, Okot. The Horn of My Love. London: Longman, 1974.

Sellah, Tejan. New Poets of West Africa. Lagos: Malthouse Press, 1995.

Shoja, Ayem. Aesthetics and Social Vision in Tiv Oral Poetry: A Study of Oliver Ayeh. Katsina-Ala:Climax Graphics, 2010,

Tsenongu, Moses Terhemba. "The Five Ages of Tiv Oral Poetry" in The Ker Review: A Journal of Nigerian Literature: Aboki Publishers, Vol.3 No.2, 2007

Yina, Godwin. Semiotics of Tiv Oral Poetry. Makurdi: Aboki, 2011. Print 